\title{
Potensi Selulosa dari Limbah Tandan Kosong Kelapa Sawit untuk Bahan Baku Bioplastik Ramah Lingkungan
}

\section{Cellulose Potential of Empty Fruit Bunches Waste as The Raw Material of Bioplastics Environmentally Friendly}

\author{
DIAN PURWITASARI DEWANTI \\ Pusat Teknologi Lingkungan, Badan Pengkajian dan Penerapan Teknologi \\ Gedung 820 Geostek, Kawasan Puspiptek Serpong, Tangerang Selatan \\ dianpurwitasaridewanti@gmail.com
}

\begin{abstract}
Increase in extent tree crops palm oil and production raises the waste problem. Based on data BPS in 2015, palm oil production in Indonesia reach 31.07 million tons per annum. At $23 \%$ of the palm oil production was Empty Fruit Bunches (EFB). Only $10 \%$ of EFB already used for fuel of boilers and compost even though many once product that can made from the processing EFB. One of the use of $E F B$ is to extract cellulose as raw material bioplastics environmentally friendly. This will help problem of environment posed by palm oil and the use of plastic is very much. The cellulose in EFB as much as $30-40 \%$ weight. Cellulose of the EFB extracted with two stages of the proceedings are delignification using sodium hydroxide $(\mathrm{NaOH}) 12 \%$ for 3 hours continued Bleaching with hydrogen peroxide $\left(\mathrm{H}_{2} \mathrm{O}_{2}\right) 10 \%$ for 1.5 hours. From the extraction were obtained yield cellulose of $34 \%$. From the result has been concluded that cellulose has the potential very large for produced from EFB so meet the needs of raw materials bioplastics.
\end{abstract}

Keyword: oil palm, EFB, cellulose, bioplastics, delignification

\begin{abstract}
ABSTRAK
Peningkatan luas lahan perkebunan kelapa sawit dan produksinya menimbulkan permasalahan sampah. Berdasarkan data BPS tahun 2015, produksi kelapa sawit di Indonesia mencapai 31,07 juta ton per tahun. Sebesar $23 \%$ dari total produksi kelapa sawit tersebut merupakan Tandan Kosong Kelapa Sawit (TKKS). Hanya 10\% dari TKKS yang sudah dimanfaatkan untuk bahan bakar boiler dan kompos padahal banyak sekali produk yang bisa dibuat dari hasil pengolahan TKKS. Salah satu pemanfaatan TKKS adalah dengan mengekstraksi selulosa sebagai bahan baku bioplastik ramah lingkungan. Hal ini akan membantu permasalahan lingkungan yang ditimbulkan oleh kelapa sawit dan pemakaian plastik sudah sangat banyak. Kandungan selulosa dalam TKKS sebesar $30-40 \%$ berat. Penelitian ini bertujuan menghitung potensi selulosa dari TKKS dengan mengekstraksi selulosa sehingga didapatkan yield selulosa yang terekstraksi. Selulosa dari TKKS tersebut diekstraksi dengan dua tahapan proses yaitu delignifikasi menggunakan natrium hidroksida $(\mathrm{NaOH}) 12 \%$ selama 3 jam dilanjutkan bleaching dengan hidrogen peroksida $\left(\mathrm{H}_{2} \mathrm{O}_{2}\right)$ 10\% selama 1,5 jam. Dari hasil ekstraksi tersebut didapatkan yield selulosa sebesar $34 \%$. Dari hasil tersebut dapat disimpulkan bahwa selulosa memiliki potensi yang sangat besar untuk diproduksi dari TKKS sehingga memenuhi kebutuhan bahan baku bioplastik.
\end{abstract}

Kata kunci : kelapa sawit, TKKS, selulosa, bioplastik, delignifikasi 


\section{PENDAhULUAN}

\subsection{Latar Belakang}

Berdasarkan data BPS tahun 2015, Indonesia memiliki luas perkebunan kelapa sawit sebesar 6.735.300 hektar yang tersebar di 22 propinsi dengan produksi kelapa sawit sebesar 31.070 .000 ton per tahun. Sebanyak $25-26 \%$ dari total produksi kelapa sawit tersebut merupakan tandan kosong yang menjadi produk samping. Baru sebanyak 10\% dari TKKS tersebut yang sudah dimanfaatkan untuk bahan bakar boiler maupun kompos, dan sisanya masih menjadi limbah ${ }^{(1)}$. Tabel 1 menunjukkan sebaran produksi terbesar kelapa sawit beberapa propinsi di Indonesia.

Tabel 1. Sebaran produksi terbesar kelapa sawit beberapa propinsi di Indonesia

\begin{tabular}{lcccc}
\hline \multirow{2}{*}{ Propinsi } & \multicolumn{4}{c}{ Produksi Tanaman Perkebunan } \\
\cline { 2 - 5 } (Ribu Ton) \\
\cline { 2 - 5 } & $\mathbf{2 0 1 2}$ & $\mathbf{2 0 1 3}$ & $\mathbf{2 0 1 4}$ & $\mathbf{2 0 1 5}$ \\
\hline $\begin{array}{l}\text { SUMATERA } \\
\text { UTARA }\end{array}$ & 3975.43 & 4549.2 & 4870.2 & 5193.1 \\
\hline RIAU & 6384.54 & 6647 & 6993.2 & 8059.8 \\
\hline JAMBI & 1718.29 & 1749.62 & 1773.7 & 1794.9 \\
\hline $\begin{array}{l}\text { SUMATERA } \\
\text { SELATAN }\end{array}$ & 2492.9 & 2690.62 & 2791.8 & 2821.9 \\
\hline $\begin{array}{l}\text { KALIMANTAN } \\
\text { TIMUR }\end{array}$ & 1298.14 & 1349.78 & 1407.3 & 1586.6 \\
\hline
\end{tabular}

TKKS tersusun dari beberapa zat penting yang dapat dimanfaatkan dan diolah menjadi bahan lain yang lebih bernilai ekonomi. Komponen penyusunnya antara lain selulosa, lignin, holoselulosa, hemiselulosa, air dan zat ekstraktif lain. Komposisi zat penyusun TKKS dapat dilihat pada tabel 2 .

Tabel 2. Komposisi zat penyusun TKKS ${ }^{(2)}$

\begin{tabular}{ll}
\hline Komposisi & Kadar (\%) \\
\hline Kadar Air & 8,56 \\
\hline Lignin & 25,83 \\
\hline Holoselulosa & 56,49 \\
\hline Selulosa & 33,25 \\
\hline Hemiselulosa & 23,24 \\
\hline Zat Ekstratif & 4,19 \\
\hline
\end{tabular}

Salah satu bahan yang sangat penting dari TKKS yang bisa dimanfaatkan menjadi produk lain yang bernilai tinggi adalah selulosa. Selulosa merupakan polimer alam yang dapat digunakan sebagai bahan baku pembuatan kain, bioetanol, dan bioplastik dengan mensintesisnya menjadi selulosa asetat. Selulosa yang terkandung dalam TKKS adalah $38,76 \%{ }^{(3)}$ atau sekitar $37,50 \%$ dengan kandungan serat mencapai $72,67 \%{ }^{(4)}$. Karena tingginya kandungan selulosa tersebut menyebabkan TKKS potensial menjadi raw material untuk diambil selulosanya.

Selulosa menjadi penting untuk diekstraksi sebagai bahan baku pembuatan bioplastik karena pemakaian plastik yang semakin besar akan menyebabkan pencemaran lingkungan. Bahan plastik akan mengganggu kesehatan manusia dan mencemari lingkungan karena plastik mempunyai sifat sulit terdegradasi dan membutuhkan waktu 100 hingga 500 tahun hingga dapat terdekomposisi dengan sempurna. Sedangkan bioplastik dari selulosa memilki sifat biodegradable dan dapat terurai hingga $67 \%$ dalam waktu 2 - 3 minggu pada media sludge aktif pengolahan air limbah (5).

Persiapan sebelum ekstraksi selulosa adalah mencuci bersih TKKS dan memotong-motong dengan ukuran $3-5 \mathrm{~cm}$. Ekstraksi dilakukan dengan dua tahapan proses yaitu delignifikasi menggunakan larutan natrium hidroksida $(\mathrm{NaOH})$ $12 \%$ (b/v) dalam waktu 3 jam pada suhu $90-95$ ${ }^{\circ} \mathrm{C}$ dan dilanjutkan dengan proses bleaching menggunakan larutan hidrogen peroksida $\left(\mathrm{H}_{2} \mathrm{O}_{2}\right)$ $10 \%(\mathrm{~b} / \mathrm{v})$ dalam waktu $1,5 \mathrm{jam}^{(6)}$.

Selulosa tidak dapat langsung diproses menjadi bioplastik. Hal ini disebabkan karena selulosa tidak dapat larut dalam kebanyakan pelarut ${ }^{(7)}$. Untuk membentuk bioplastik, selulosa diasetilasi dengan asetat anhidrat untuk menghasilkan selulosa asetat ${ }^{(8)}$. Selulosa bisa diproses dengan asetilasi( ${ }^{(9)}$ menjadi selulosa ester seperti selulosa (di)asetat dan selulosa (tri)asetat yang selanjutnya dikonversi menjadi material termoplastik. Untuk tujuan pembuatan bioplastik yang berupa lembaran maka yang dikehendaki adalah selulosa diasetat ${ }^{(10)}$ atau selulosa sekunder dengan derajat subtitusi 1,21,9. Proses konversi membutuhkan bahan tambahan seperti Poli Etilen Glikol (PEG) dan dilanjutkan proses fisika yang meliputi laminating, injeksi atau ekstrusi sehingga terbentuk lembaran ${ }^{(11)}$.

\subsection{Tujuan Penelitian}

Penelitian ini bertujuan menghitung potensi selulosa dari TKKS dengan mengekstraksi selulosa sehingga didapatkan persen yieldnya. Analisa FTIR dilakukan untuk mengetahui panjang gelombang selulosa hasil ekstraksi dan dilihat serapan gelombang pada gugus fungsi pembentuk selulosa untuk mengetahui bahwa yang diekstraksi adalah benar selulosa.

Dari yield yang didapat maka dapat dihitung potensi selulosa TKKS dari total produksi kelapa sawit di Indonesia sebagai bahan baku bioplastik yang ramah lingkungan menggantikan plastik yang selama ini berbahan baku dari minyak bumi.

\section{BAHAN DAN METODE}

Bahan yang akan diekstraksi untuk diambil selulosanya adalah TKKS dari pohon kelapa 
sawit di Kompleks Perkantoran Puspiptek Serpong. TKKS dicuci bersih kemudian dikeringkan dalam oven dan dipotong-potong dengan ukuran $3-5 \mathrm{~cm}$. TKKS kemudian didelignifikasi menggunakan larutan $\mathrm{NaOH} 12 \%$ (b/v) selama 3 jam pada suhu yang dijaga $90-$ $95{ }^{\circ} \mathrm{C}$. Setelah itu larutan didinginkan dan disaring untuk mendapatkan selulosa yang terpisah dari $\mathrm{NaOH}$ dan komponen lain dari TKKS.

Proses selanjutnya adalah bleaching menggunakan larutan $\mathrm{H}_{2} \mathrm{O}_{2} 10 \%(\mathrm{~b} / \mathrm{v})$ selama 1,5 jam dengan suhu yang dijaga $80-90{ }^{\circ} \mathrm{C}$. Selanjutnya selulosa dicuci bersih dengan akuades hingga $\mathrm{pH}$ netral dan didapatkan selulosa dengan kemurnian tinggi. Dari hasil ekstraksi tersebut, dapat dihitung persen yield selulosa yang terekstraksi. Untuk memastikan bahwa selulosa yang terekstraksi maka dilakukan analisa FTIR.

Dari persen yield selulosa yang didapat, potensi selulosa dari TKKS yang dapat dimanfaatkan untuk bioplastik dapat dihitung dengan rumus sebagai berikut :

\section{Potensi selulosa (ton) \\ $=$ jumlah produksi kelapa sawit (ton) $\mathrm{x} \%$ TKKS $x \%$ selulosa $x$ yield selulosa....(1).}

Potensi bioplastik yang dapat dibuat

$$
\begin{aligned}
= & \text { potensi selulosa (ton) } x \text { yield selulosa } \\
& \text { asetat } \ldots \ldots \ldots \ldots \ldots \ldots \ldots \ldots \ldots \ldots \ldots \ldots \ldots \ldots \ldots \ldots \ldots \ldots \ldots \ldots \ldots
\end{aligned}
$$

\section{HASIL DAN PEMBAHASAN}

TKKS merupakan hasil samping perkebunan kelapa sawit yang beratnya mencapai $23 \%$ dari berat tandan segar kelapa sawit. Selama ini baru $10 \%$ dari TKKS yang dimanfaatkan. Diantaranya adalah untuk bahan bakar ketel uap dan kompos. Sisa TKKS lain yang belum termanfaatkan menjadi masalah sampah. Dalam TKKS terdapat beberapa komponen penyusun yang dapat diekstraksi dan dimanfaatkan menjadi produk lain yang lebih berharga. Salah satu komponen TKKS tersebut adalah selulosa. Selulosa merupakan bahan penyusun TKKS dengan persentase paling besar yaitu sekitar $30-40 \%$.

Selulosa dari TKKS dapat dimurnikan melalui dua tahap proses yaitu delignifikasi yang dilanjutkan dengan bleaching. Deliginfikasi merupakan proses yang bertujuan melarutkan komponen lain dari TKKS selain selulosa. Dalam penelitian ini deliginifikasi menggunakan $\mathrm{NaOH}$ $12 \%(b / v)$ pada suhu yang dijaga $90-95{ }^{\circ} \mathrm{C}$ selama 3 jam. Melalui deliginifikasi diharapkan komponen seperti hemiselulosa, lignin, holoselulosa, dan komponen lain dapat larut. $\mathrm{NaOH}$ dipilih karena lignin lebih larut dalam kondisi alkali dan selulosa tidak ${ }^{(12)}$.

Konsentrasi $\mathrm{NaOH}$ yang digunakan pada proses delignifikasi tidak boleh melebihi $17 \%$ karena selulosa akan mengalami perubahan struktur yang sangat berbeda dari aslinya pada konsentrasi $\mathrm{NaOH} 15-20 \%{ }^{(13)}$. Selanjutnya selulosa yang didapat dari proses deliginifikasi disaring untuk memisahkan dengan pelarutnya. Selulosa yang didapat masih berwarna cokelat gelap karena masih ada pigmen dan sisa lignin yang masih terikut dalam selulosa. Gambar 1 menunjukkan warna TKKS dalam larutan $\mathrm{NaOH}$ $12 \%$.

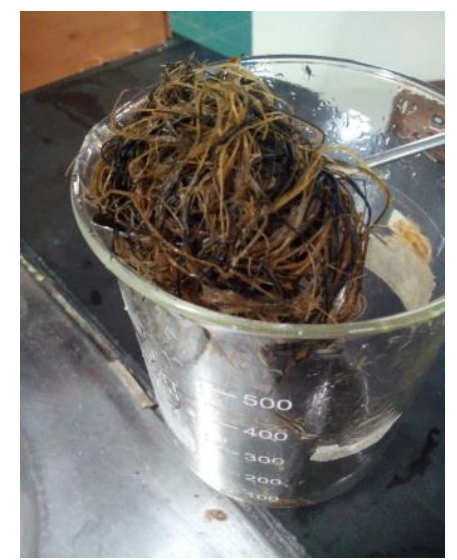

Gambar 1. TKKS yang sedang didelignifikasi

Untuk menghilangkan pigmen dan sisa lignin, maka dilakukan proses lanjutan yaitu proses bleaching dengan hidrogen peroksida $\left(\mathrm{H}_{2} \mathrm{O}_{2}\right)$. Pemilihan larutan $\mathrm{H}_{2} \mathrm{O}_{2}$ untuk bleaching karena $\mathrm{H}_{2} \mathrm{O}_{2}$ berbasis oksigen yang sangat efisien, efisien, low cost, dan sedikit menimbulkan pencemaran lingkungan ${ }^{(14)}$. Selulosa hasil ekstraksi yang akan di bleaching masih berwarna kuning terang ${ }^{(15)}$. $\mathrm{H}_{2} \mathrm{O}_{2}$ yang digunakan adalah larutan $\mathrm{H}_{2} \mathrm{O}_{2} \quad 10 \%$ (b/v). Bleaching dilakukan dengan pemanasan pada suhu $85-90{ }^{\circ} \mathrm{C}$ selama 1,5 jam. Bleaching pada waktu kurang dari 1,5 jam akan menghasilkan tingkat kecerahan selulosa yang masih rendah, akan tetapi ketika bleaching lebih dari 1,5 jam, tingkat kecerahan selulosa cenderung konstan. Sehingga, waktu 1,5 jam dipilih karena kondisinya paling optimum. Begitu pula suhu yang digunakan untuk bleaching, suhu optimum adalah $80^{\circ} \mathrm{C}^{(14)}$. Kondisi selulosa ketika sedang di bleaching terlihat seperti gambar 2 .

Setelah selesai bleaching didapatkan selulosa yang berwarna putih bersih/cerah. Warna putih cerah tersebut menunjukkan bahwa pigmen serta lignin sudah larut sehingga didapatkan selulosa dengan kemurnian tinggi. Gambar 3 menunjukkan pengaruh waktu dan suhu bleaching dengan tingkat kecerahan selulosa. 

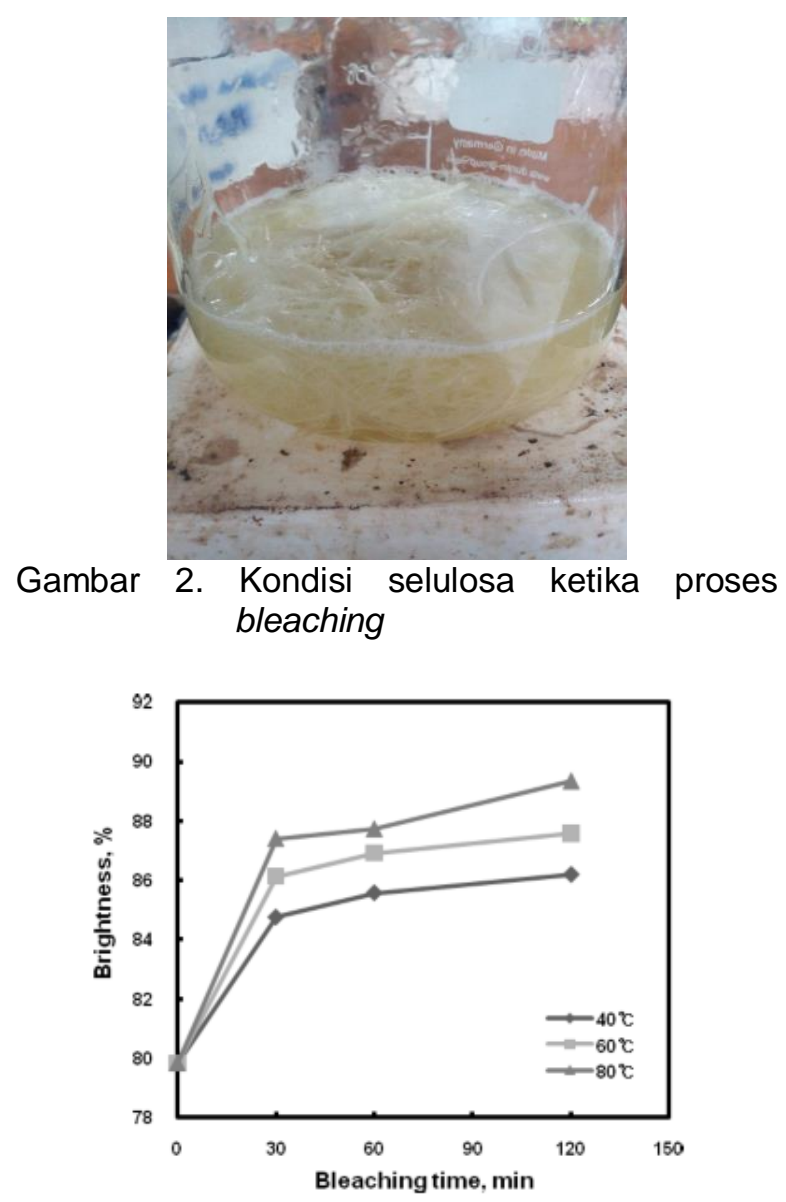

Gambar 3. Efek waktu dan suhu bleaching dengan tingkat kecerahan selulosa

Selulosa yang didapat kemudian dicuci bersih berulang-ulang menggunakan akuades hingga $\mathrm{pH}$ netral. Pemanasan dilakukan untuk menghilangkan sisa air yang masih tersisa dalam selulosa. Selulosa yang didapatkan setelah pemanasan seperti ditunjukkan pada gambar 4 .

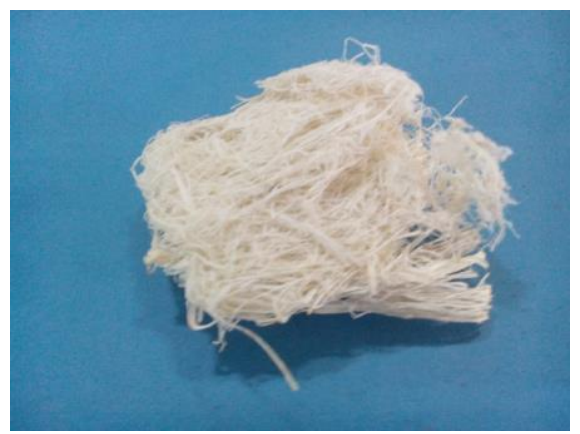

Gambar 4. Selulosa TKKS

Selanjutnya berat selulosa dihitung untuk mengetahui persen yield yang didapat. Dari hasil penelitian ini, dari 10 gram TKKS yang diekstraksi, didapatkan selulosa sebesar 3,4 gram. Sehingga persen yield selulosa yang diperoleh, dapat dihitung dengan rumus 1 .

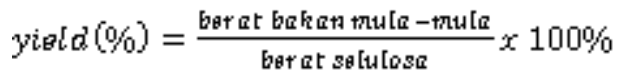

Hasil ekstraksi selulosa dengan $\mathrm{NaOH} 12 \%$ didapatkan yield selulosa sebesar $34 \%$. Selulosa yang dapat diekstraksi dengan delignifikasi $\mathrm{NaOH}$ dan bleaching $\mathrm{H}_{2} \mathrm{O}_{2}$ ini mencapai $80 \%$ dari total selulosa yang terkandung dalam TKKS.

Pada penelitian sebelumnya dengan $\mathrm{NaOH}$ $10 \%$ pada suhu $60{ }^{\circ} \mathrm{C}$ selama 90 menit, didapatkan yield sebesar $43,22 \%{ }^{(16)}$. Berdasarkan penelitian lain pada ekstraksi selulosa dengan deliginifkasi $\mathrm{NaOH} 4 \%$ wt dan bleaching dengan $\mathrm{H}_{2} \mathrm{O}_{2} 7,2 \%$ wt yield selulosa yang didapat sebesar $8,35 \%{ }^{(17)}$. Selulosa yang didapatkan dengan $500 \mathrm{ml}$ larutan $\mathrm{NaOH} 2 \%$ pada suhu $80^{\circ} \mathrm{C}$ selama 30 menit memiliki kadar kemurnian sebesar $94,26 \%{ }^{(18)}$. Selulosa juga dapat diekstraksi dengan delignifikasi dengan $500 \mathrm{ml} \mathrm{NaOH} 17,5 \%$ pada suhu $80^{\circ} \mathrm{C}$ selama 30 menit ${ }^{(19)}$.

Banyak sedikitnya selulosa yang dapat diekstraksi dipengaruhi oleh beberapa faktor diantaranya adalah konsentrasi $\mathrm{NaOH}$, suhu, dan karakteristik dari TKKS yang menjadi bahan baku utamanya.

$\mathrm{NaOH}$ dalam proses delignifkasi berfungsi untuk melarutkan komponen lain selain selulosa dalam TKKS sehingga diharapkan akan didapat selulosa dengan kemurnian yang tinggi. Pada penelitian ini, $\mathrm{NaOH}$ sebesar $12 \%$ menghasilkan yield yang cukup tinggi yaitu mencapai $80 \%$ dari total selulosa yang terkandung dalam TKKS. Hal ini karena konsentrasi $\mathrm{NaOH}$ yang digunakan sudah cukup untuk mengekstraksi selulosa TKKS. Pada konsentrasi yang lebih rendah akan didapatkan yield selulosa yang rendah sedangkan pada konsentrasi yang terlalu tinggi akan menyebabkan yield selulosa yang didapat menurun ${ }^{(14)}$.

Selain pengaruh konsenrasi $\mathrm{NaOH}$, faktor lain yang mempengaruhi adalah suhu operasi. Pada penelitian ini suhu dijaga kurang dari $100{ }^{\circ} \mathrm{C}$ dengan tujuan agar tidak banyak air yang menguap atau hilang selama proses, karena dengan berkurangnya jumlah air dalam larutan akan menyebabkan peningkatan konsentrasi $\mathrm{NaOH}$ sehingga menurunkan yield selulosa yang diharapkan.

Selain kedua faktor diatas, karakteristik TKKS yang menjadi bahan baku juga berpengaruh. Karena kandungan selulosa dari tiap TKKS juga berbeda yang dipengaruhi oleh distribusi nutrisinya. Sehingga, hasil selulosa yang didapatkan akan berbeda meskipun sumber TKKS adalah dari pohon kelapa sawit yang sama.

Untuk memastikan bahwa selulosa hasil ekstraksi dari penelitian ini adalah benar selulosa, maka dilakukan karakterisasi menggunakan analisa FTIR untuk melihat gugus fungsi pembentuk selulosa yang terdapat dalam sampel selulosa yang diuji. Gambar 5 menunjukkan hasil FTIR selulosa TKKS dari penelitian ini. 


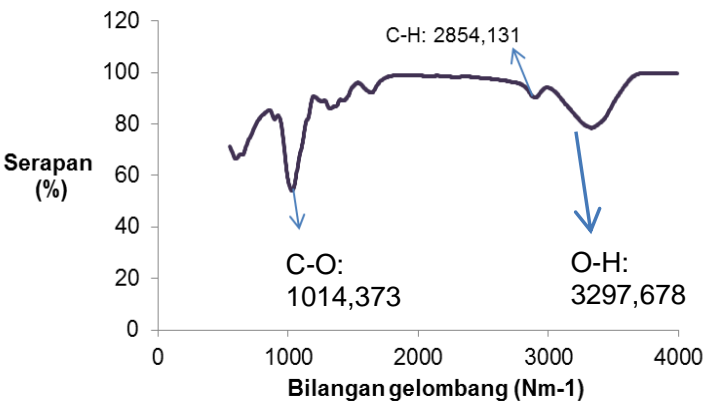

Gambar 5. Analisa FTIR selulosa TKKS

Berdasarkan hasil analisa FTIR didapatkan bilangan gelombang untuk gugus fungsi spesifikasi selulosa TKKS yaitu gugus $\mathrm{O}-\mathrm{H}$ pada daerah $3297,678 \mathrm{~cm}^{-1}$, C-H pada $2854,131 \mathrm{~cm}^{-1}$ dan C-O pada 1014,37 $\mathrm{cm}^{-1}$. Hasil analisis FTIR dari penelitian ini menunjukkan hasil yang mendekati sama dengan penelitian sebelumnya yaitu gugus $\mathrm{O}-\mathrm{H}$ pada daerah $3348 \mathrm{~cm}-1, \mathrm{C}-\mathrm{H}$ pada $2901 \mathrm{~cm}-1$ dan C-O pada $1065 \mathrm{~cm}-1^{(8)}$.

Berdasarkan hasil ekstraksi tersebut dapat dihitung berapa potensi selulosa yang dapat diekstraksi dari limbah TKKS yang ada di Indonesia saat ini. Berdasarkan neraca massa bahan, setiap tandan buah segar (TBS) sawit yang diolah di pabrik kelapa sawit akan menghasilkan 25 - 26\% TKKS $^{(4)}$. Perhitungan potensi pemanfaatan selulosa adalah sebagai berikut :

Total TKKS per tahun ${ }^{(4)}$

$=25 \% \times 31.070 .000$ ton

$=7.767 .500$ ton

TKKS yang sudah dimanfaatkan sebesar

$=10 \% \times 7.767 .500$ ton

$=776.750$ ton $^{(1)}$

TKKS yang menjadi limbah

$=7.767 .500-776.750$

$=6.990 .750$ ton

Potensi selulosa dengan kandungan 37,5\% dari $\mathrm{TKKS}^{(4)}$ :

$=2.621 .531$ ton

Apabila selulosa yang dapat diekstraksi adalah sebesar $80 \%$ dari total selulosa dalam TKKS, maka potensi selulosa sebesar 2.097.225 ton. Sehingga, dari hasil perhitungan dapat dilihat bahwa potensi selulosa yang dapat diekstraksi untuk kemudian diolah menjadi bahan baku bioplastik adalah 2.097.225 ton per tahun.

Data produksi plastik di Indonesia pada tahun 2015 adalah sebesar 2,6 juta ton. Plastik - plastik yang digunakan tersebut selanjutnya akan menjadi limbah yang dapat mencemari lingkungan. Hal ini karena sifat plastik yang tidak dapat diuraikan dengan cara alami oleh lingkungan dan membutuhkan waktu puluhan hingga ratusan tahun untuk dapat terdegradasi dengan sempurna. Dengan melihat data tersebut, sangat mendesak untuk dilakukan produksi plastik yang berbasis bahan alam yang dapat dengan cepat terurai secara alami dengan ketersediaan bahan baku yang besar. Sehingga, selulosa TKKS sangat potensial untuk dimanfaatkan menjadi bahan baku bioplastik menggantikan plastik yang dibuat dari bahan fosil.

Selulosa yang nantinya disintesis menjadi selulosa asetat dan menjadi membran/bioplastik dapat dihidrolisis menggunakan cara kimiawi maupun hayati. Hidrolisis secara hayati dengan menggunakan enzim murni atau mikroorganisme penghasil enzim selulosa ${ }^{(22)}$. Dengan metode penguburan dalam media tanah yang mengandung mikroorganisme, membran selulosa asetat dapat terdegradasi dalam waktu 5 minggu dengan melihat hasil analisa SEM yang terlihat lubang-lubang membran akibat degradasi ${ }^{(23)}$. Sehingga, apabila selulosa diproses menjadi bioplastik untuk menggantikan plastik dari minyak bumi maka permasalahan lingkungan yang disebabkan oleh lamanya proses penguraian bisa teratasi. Hal ini karena waktu degradasi bioplastik yang sangat cepat (5 minggu) dibandingkan plastik dari minyak bumi yang memerlukan waktu ratusan tahun agar bisa terdegradasi.

Proses sintesis bioplastik dengan bahan selulosa dimulai dengan sintesis selulosa dengan asam asetat anhidrat ${ }^{(24)}$ sehingga membentuk selulosa asetat. Pada sintesis selulosa asetat dengan TKKS dan asam asetat anhidrat sebagai reaktan dan katalis $\mathrm{H}_{2} \mathrm{SO}_{4}{ }^{(25,26)}$ sebanyak $1 \%$ (v/v) menghasilkan yield sebesar $17,28 \%$. Ini artinya, dari massa total selulosa yang direaksikan, didapatkan selulosa asetat sebesar $17,28 \%{ }^{(20)}$. Sintesis selulosa asetat dengan pelarut asam asetat anhidrat dengan katalis iodin dapat menghasilkan selulosa asetat dengan konversi sebesar $50-80 \%{ }^{(21)}$.

Apabila potensi selulosa yang dapat diproduksi dari TKKS sebesar 2.097.225 ton dengan yield selulosa asetat yang dapat dihasilkan sebesar 17,28\%, maka potensi bioplastik yang dapat diproduksi sebesar $362.400,48$ ton. Sehingga dengan kebutuhan plastik per tahun yang mencapai 2,6 juta ton, maka plastik yang dapat disubtitusi dengan bioplastik berbahan baku selulosa TKKS adalah sebesar $17,3 \%$. 


\section{KESIMPULAN}

Potensi selulosa dari TKKS yang dapat dimanfaatkan untuk produksi bioplastik adalah 2.097.225 juta ton dengan asumsi yield bioplastik yang didapatkan sebesar $17,28 \%$ maka $17,3 \%$ plastik dapat digantikan dengan bioplastik. Sehingga, pencemaran lingkungan yang diakibatkan oleh limbah plastik dapat dikurangi.

\section{PERSANTUNAN}

Ucapan terima kasih diberikan kepada lbu Dewi Tristatini, Ph.D dan Ibu Dr. Eny Kusrini selaku Dosen Teknik Kimia Universitas Indonesia serta Dr. M. Hanif, M. Eng yang telah membimbing penelitian ini sehingga didapatkan data hasil ekstraksi selulosa dari TKKS serta hasil karakterisasinya dengan analisa FTIR.

\section{DAFTAR PUSTAKA}

1. Ngadi, N., \& Lani, N. S. (2014). Extraction and Characterization of Cellulose Acetate from Empty Friut Bunch (EFB) Fiber. Jurnal Teknologi, 35-36.

2. Sudiyani, Y. (2009). Utilzation of Biomass Waste Empty Fruuit Bunch Fiber of Palm Oil for Bioethanol Production. Reassearch Workshop on Sustainable Biofuel, (pp. 115). Jakarta.

3. Bahmid, N. A., Syamsu, K., \& Maddu, A. (2014). Pengaruh Ukuran Serat Selulosa Asetat dan Penambahan Dietilen Glikol (DEG) terhadap Sifat Fisik dan Mekanik Bioplastik . Jurnal Teknologi Industri Pertanian, 226-234.

4. Herawan, T., \& Rivani, M. (2010). Produksi Aseton-Butanol-Etanol dari Hidrolisat Tandan Koosng Kelapa Sawit. Laporan Pnelitian Kerjasama PPKS-PTPN IV, 16.

5. Puls, J. (2011). Degradation of Cellulose Acetate-Base Material. Jpolumenviron, 152154.

6. Biswas, A., Selling, G., Appell, M., Woods, K., Willet, J., \& Buchanan, C. (2007). lodine Catalized Esterification of Cellulose Using Reduced Levels of Solvent. Carbohydrat Polymers, 555-560.

7. Rachmaniah, O., Febriyanti, L., \& Lazuardi, K. (2009). Pengaruh Liquid Hot Water terhadap Perubahan Struktur Sel Bagas. Prosiding Seminar Nasional XIV (pp. 30-40). Surabaya: FTI-ITS.
8. Bahmid, N. A., Syamsu, K., \& Maddu, A. (2013). Production of Cellulose Acecate from Oil Palm Empty Fruit BUnches Cellulose. Chemical and Process Engineering Research, 12-15.

9. Granstrom, M. (2009). Cellulose Derivatives : Synthesis, Properties and Applications. Finland: University of Helsinki.

10. Gaol, M. L., Sitorus, R., Surya, I., \& Manurung, R. (2013). Pembuatan Selulosa Asetat dari Alfa-Selulosa Tandan Kosong Kelapa Sawit. Jurnal Teknik Kimia USU, 3339.

11. Jabeen, N., Majid, I., \& Nayik, A. (2015). Bioplastics anf Food Packaging: A review. Cogen, Food \& Agriculture, 1-6.

12. Herawan, T., \& Rivani, M. (2010). Produksi Aseton-Butanol-Etanol dari Hidrolisat Tandan Koosng Kelapa Sawit. Laporan Pnelitian Kerjasama PPKS-PTPN IV, 16.

13. Anonim. (2014). Chemical composition and Structure of NAtural Lignocellulose. Biotechnolgy of Lignocellulose, 25-71.

14. Li, L., Lee, S., Lee, L. H., \& Youn, J. H. (2011). Hydrogen Peroxide Bleaching of Hardwood Kraft Pulp with Adsorbed Birch Xylan and Its Effect on Paper Properties. Bioreasources, 721-736.

15. Nazir, M. S., Wahjoedi, B. A., Yussof, A. W., \& Abdullah, M. A. (2013). Eco-Frinedly Extraction and Characterization of Cellulose from Oil Palm Empty Fruit Bunches. BioResources, 2161-2172.

16. Asri, M., \& Ramli, S. (2015). Characterization of Cellulose Extracted from Oil Palm Empty Fruit Bunch. AIP Conf.Proc. 1687,050016, 1-5.

17. Julianto, H., Farid, M., \& Rasyida, A. (2017). Ekstraksi Nanoselulosa dengan Metode Hidrolisis Asam sebagai Penguat Komposit Absorpsi Suara. Jurnal Teknik ITS Vol.6, No.2, 243-246.

18. Nurul, T. (2016). Pengaruh Konsentrasi $\mathrm{NaOH}$ pada Karakterisasi Alfa-Selulosa dari Tandan Kosong Sawit (TKS). Bandar Lampung: Fakultas FMIPA Universitas Lampung.

19. Nosya, M. A. (2016). Pembuatan Mikrokristal Selulosa dari Tandan Kosong 
Kelapa Sawit. Bandar Lampung: Fakultas FMIPA Universitas Lampung.

20. Tristantini, D., Kusrini, E., \& Dewanti, D. P. (2017). Synthesis and Characterization of Cellulose Acetate from Natural Fiber as A Subtitute Microbeads Polyethylene Environmentally Friendly. IOP Conference Series : Materials Science and Engineering.

21. Cheng, H., Dwod, M., Selling, G., \& Biswas, A. (2010). Synthesis of Cellulose Acetate from Cotton Byproducts. Carbohydrat POlymer, 449-452.

22. Hardjo, S., Indrasti, N., \& Bantacut, T. (1989). Biokonversi Pemanfaatan Limbah Pertanian. Bogorr: PAU PAngan dan Gizi IPB.

23. Istiqlalah, A. (2006). Biodegradasi Membran Selulosa Asetat Berpori dari Limbah Kulit Nanas Menggunakan Bacillus subtillis. Bogor: Departemen KImia FMIPA IPB.

24. Taubman, E. (1935). Preparation of Cellulose Acetate with Acetic Acid. Massachusetts Institute of Technology.

25. Bikales, N., \& Segl, L. (1971). Cellulose and Cellulose derivatives. High Polymers Series.

26. Biswas, A., Selling, G., Appell, M., Woods, K., Willet, J., \& Buchanan, C. (2007). lodine Catalized Esterification of Cellulose Using Reduced Levels of Solvent. Carbohydrat Polymers, 555-560. 
